\title{
Agronomic Manipulation on Seed Cotton Yield and Nitrogen, Phosphorus and Potassium uptake in Compact Cotton cv. co 17
}

\author{
A. Arun ${ }^{1 *}$, T. Ragavan ${ }^{2}$, A. Gurusamy ${ }^{1}$, P. Saravana Pandian ${ }^{3}$ and M. Gunasekaran ${ }^{4}$ \\ ${ }^{1}$ Department of Agronomy, Agricultural College and Research Institute, \\ Madurai, Tamil Nadu, India \\ ${ }^{2}$ Coastal Saline Research Centre, Ramanathapuram, Tamil Nadu, India \\ ${ }^{3}$ Department of Soils and Environment, India \\ ${ }^{4}$ Regional Research Station, Aruppukottai, Virudhunagar, Tamil Nadu, India \\ *Corresponding author
}

\section{A B S T R A C T}

The manipulation of crop geometry along with different levels of $\mathrm{N}, \mathrm{P}$ and $\mathrm{K}$ is a time tested agronomic techniques to enhance the yield potential of cotton. In addition to the

Keywords

Compact cotton,

Crop geometry,

Levels of nutrients and Nutrients

uptake

Article Info

Accepted:

04 December 2020

Available Online:

10 January 2021 above, to facilitate mechanical harvesting, field experiments were conducted during summer season of 2019 and rabi season of 2019-20. The experiments were laid out in split plot design replicated thrice with four plant spacing in main plots viz., $S_{1^{-}} 100 \times 10 \mathrm{~cm}, S_{2^{-}}$ $75 \times 15 \mathrm{~cm}, \mathrm{~S}_{3}-60 \times 15 \mathrm{~cm}$ and $\mathrm{S}_{4}-45 \times 15 \mathrm{~cm}$ and four levels of nutrient levels in sub plot viz., Control (without fertilizers), $\mathrm{F}_{1}-100 \%$ RDF (80:40:40 kg of NPK ha ${ }^{-1}$ ), $\mathrm{F}_{2}-125 \%$ RDF (100:50:50 kg of NPK ha ${ }^{-1}$ ) and $F_{3}-150 \%$ RDF (120:60:60 kg of NPK ha $\left.{ }^{-1}\right)$. The results from the pooled analysis (two season data) revealed that the nitrogen, phosphorus and potassium uptake were significantly influenced by the crop geometry and nutrient levels. The highest uptake of nitrogen 94.39 and $93.19 \mathrm{kgha}^{-1}$ were recorded in $\mathrm{S}_{3} \mathrm{~F}_{3}(60 \mathrm{x}$ $15 \mathrm{~cm}$ with 150\%RDF-120:60:60 kg NPK ha $\left.{ }^{-1}\right)$ and in $\mathrm{S}_{1} \mathrm{~F}_{3}(100 \times 10 \mathrm{~cm}$ with $150 \% \mathrm{RDF}-$ 120:60:60 kg NPK ha ${ }^{-1}$ ), respectively and were found to be on par with each other. These two treatments combination also registered highest uptake of phosphorous $15.47 \mathrm{~kg} \mathrm{ha}^{-1}$ in $\mathrm{S}_{3} \mathrm{~F}_{3}$ and $15.16 \mathrm{~kg} \mathrm{ha}^{-1}$ in $\mathrm{S}_{1} \mathrm{~F}_{3}$ and potassium $85.44 \mathrm{~kg} \mathrm{ha}^{-1}$ in $\mathrm{S}_{3} \mathrm{~F}_{3}$ and $84.24 \mathrm{~kg} \mathrm{ha}^{-1}$ in $\mathrm{S}_{1} \mathrm{~F}_{3}$. The maximum seed cotton yield of $2475 \mathrm{~kg} \mathrm{ha}^{-1}$ was recorded in $\mathrm{S}_{3} \mathrm{~F}_{2}(60 \mathrm{x} 15 \mathrm{~cm}$ with 125\%RDF-10:50:50 kg NPK ha $\left.{ }^{-1}\right)$ followed by $\mathrm{S}_{1} \mathrm{~F}_{2}(60 \times 15 \mathrm{~cm}$ with $150 \% \mathrm{RDF}-$ 120:60:60 kg NPK ha ${ }^{-1}$ ) which recorded $2395 \mathrm{~kg} \mathrm{ha}^{-1}$ and were found to be on par.

\section{Introduction}

Cotton (Gossypium spp.), the king of fibre or white gold, is one of the most important commercial crop of India. It is one of the most important cash crops next to food grains that play a vital role in Indian national economy (Patel et al., 2016). In India, cotton is grown over an area 105 lakh hectares with production 351 lakh bales and productivity of $568 \mathrm{~kg}$ lint ha ${ }^{-1}$ (Parikar et al., 2018). Cotton yield can only be increased through proper crop management practices of which optimum nutrient levels and plant population are most 
important (Ali et al., 2007). Optimizing plant density and fertilizer levels are, therefore, the target for improved management. The nutrient management in cotton is a complex phenomenon due to its long duration and in determining growth habit, where simultaneous production of vegetative and reproductive structure during the active growth phase takes place (Kharagkharate et al., 2017). The NPK are key nutrients required in large quantities by all crop plants and classed as major nutrient elements for plants. Cotton growth, development and maturity are greatly influenced by NPK fertilizers application which ultimately increases yield components, yield and fiber quality (Shah et al., 2017). The manipulation of crop geometry is a agronomic technique to improve yield and profitability of cotton. As plant density increases the cumulative demand for solar radiation, water and nutrient are increase and leading to more canopy cover and decreased soil water evaporation, is becoming popular to address water scarcity challenges (Hou et al., 2007; Venugopalan et al., 2014). Hence, an attempt has been made to study the uptake pattern of N,P and K as influenced by crop geometry and nutrients levels. In addition to the above, seed cotton yield was studied.

\section{Materials and Methods}

Experiments were conducted at Central farm, Department of Agronomy, Agriculture College and Research Institute (TNAU), Madurai during summer season of 2019 (season I) and rabi season of 2019-20 (season II). The experiments were laid out in split plot design replicated thrice with four plant densities viz., $S_{1}-100 \times 10 \mathrm{~cm} \quad(1,00,000$ plants $\left.\mathrm{ha}^{-1}\right), \mathrm{S}_{2}-75 \times 15 \mathrm{~cm}(88,888$ plants ha $\left.{ }^{1}\right), S_{3}-60 \times 15 \mathrm{~cm}\left(1,11,111\right.$ plants ha $\left.{ }^{-1}\right)$ and $S_{4}$ $-45 \times 15 \mathrm{~cm}\left(1,48,148\right.$ plants ha $\left.{ }^{-1}\right)$ in main plot and four levels of NPK viz., Control (without fertilizers), $\mathrm{F}_{1}-100 \% \mathrm{RDF}$ (80:40:40 $\mathrm{kg}$ of
NPK ha $\left.{ }^{-1}\right), \mathrm{F}_{2}-125 \%$ RDF (100:50:50 kg of NPK ha ${ }^{-1}$ ) and $\mathrm{F}_{3}-150 \%$ RDF (120:60:60 kg of NPK ha ${ }^{-1}$ ) in sub plot. The compact cotton variety $\mathrm{cv}$. CO 17 was used for the present investigation. The seed cotton yield was assessed in both season and were pooled prior statistical analysis. The whole plant dry weight including seed cotton yield was used for analysing nitrogen, phosphorous and potassium content (Jackson, 1973) and the uptake were calculated as per method suggested by Balakrishnan et al., (2020)and expressed in $\mathrm{kg} \mathrm{ha}^{-1}$.

\section{Results and Discussion}

\section{Uptake of nutrients}

\section{Nitrogen $(\mathbf{N})$}

Nitrogen $(\mathrm{N})$ is an essential macronutrient that is required most consistently and in larger amounts than other nutrients for cotton production (Hou et al., 2007). It is an essential element for canopy area development and photosynthesis (Wullschleger and Oosterhuis, 1990). Nitrogen fertilization had significant impacts on plant growth, lint yields and fiber quality (Boquet et al., 1993; Bondada et al., 1996). In the present investigation, data on nitrogen uptake observed in both season I and season II, pooled and statistically analysed (Table 1). Data on $\mathrm{N}$ uptake pertaining to the first season (summer season of 2019) revealed that it was significantly altered by spacing and nutrient levels. Among the various $60 \times 15$ $\mathrm{cm}-1,11,111$ plants $\mathrm{ha}^{-1}\left(\mathrm{~S}_{3}\right)$ recorded the highest nitrogen uptake $\left(76.01 \mathrm{~kg} \mathrm{~h}^{-1}\right)$ and followed by $100 \times 10 \mathrm{~cm}\left(S_{1}\right)$ which recorded $76.68 \mathrm{~kg} \mathrm{~N} / \mathrm{ha}$ and both $S_{3}$ and $S_{1}$ were found to be on par with each other. The lowest $\mathrm{N}$ uptake was registered by 88,888 plants $\mathrm{ha}^{-1}$ $\left(S_{2}\right)$ of $69.77 \mathrm{~kg} \mathrm{ha}^{-1}$. With regard to nutrient levels, application of 150\%RDF-120:60:60 kg NPK ha ${ }^{-1}\left(F_{3}\right)$ recorded highest nitrogen 
uptake $\left(92.76 \mathrm{~kg} \mathrm{ha}^{-1}\right.$ ) and control (without fertilizer) registered the lowest $\mathrm{N}$ uptake (39.91 $\left.\mathrm{kg} \mathrm{ha}^{-1}\right)$. The interaction effect was found to be significant. Data revealed that the maximum uptake of $\mathrm{N}\left(95.55 \mathrm{~kg} \mathrm{ha}^{-1}\right)$ was recorded in the treatment of combination of $60 \times 15 \mathrm{~cm}$ with $150 \% \operatorname{RDF}\left(\mathrm{S}_{3} \mathrm{~F}_{3}\right)$ and was followed by $\mathrm{S}_{1} \mathrm{~F}_{3}\left(94.23 \mathrm{~kg} \mathrm{ha}^{-1}\right)$. However, both were found to be on par with each other. The minimum $\mathrm{N}$ uptake was recorded in $\mathrm{S}_{2} \mathrm{C}$ (40.01 kg ha ${ }^{-1}$ ).

In the case of season II (rabi season of 201920), the nitrogen uptake was significantly influenced by crop geometry as well as nutrient levels. Among the plant population,60 x15 cm-1,11,111 plants $\mathrm{ha}^{-1}$ $\left(S_{3)}\right.$ recorded the maximum uptake of 73.63 $\mathrm{kg} \mathrm{ha}^{-1}$ and it was followed by $\mathrm{S}_{1}(72.15 \mathrm{~kg}$ ha ${ }^{1}$ ) and both $S_{3}$ and $S_{1}$ were found to be on par with each other. The minimum uptake of $66.83 \mathrm{~kg} \mathrm{ha}^{-1}$ was registered in crop geometry of $75 \times 15 \mathrm{~cm}-88,888$ plants ha ${ }^{-1}\left(S_{2}\right)$. While analysing the data on $\mathrm{N}$ uptake in respect of nutrient levels, it was revealed that $150 \%$ RDF-120:60:60 kg NPK ha ${ }^{-1}\left(F_{3}\right)$ recorded the highest uptake $\left(90.61 \mathrm{~kg} \mathrm{ha}^{-1}\right)$ and the lowest uptake of $37.90 \mathrm{~kg} \mathrm{ha}^{-1}$ registered in control (without fertilizer). The interaction effect was found to be significant. The highest $\mathrm{N}$ uptake was registered in the treatment combination of $60 \times 10 \mathrm{~cm}$ along with $150 \%$ $\operatorname{RDF}\left(\mathrm{S}_{3} \mathrm{~F}_{3}\right)$ which recorded a value of 93.22 $\mathrm{kg} \mathrm{ha}^{-1}$ and followed by $\mathrm{S}_{1} \mathrm{~F}_{3}\left(92.14 \mathrm{~kg} \mathrm{ha}^{-1}\right)$ and both were found to be on par with each other. The lower $\mathrm{N}$ uptake $\left(39.17 \mathrm{~kg} \mathrm{ha}^{-1}\right.$ ) was recorded in treatment combination of $75 \times 15$ $\mathrm{cm}$ with nil fertilizer $\left(\mathrm{S}_{2} \mathrm{C}\right)$.

The results of the pooled analysis of both season revealed that $\mathrm{N}$ uptake was significantly influenced by the both plant population and nutrient levels. Comparing the plant populations, the optimum plant population of $60 \times 15 \mathrm{~cm}-1,11,111$ plants $\mathrm{ha}^{-1}$ $\left(\mathrm{S}_{3}\right)$ recorded the maximum on nitrogen uptake $\left(74.81 \mathrm{~kg} \mathrm{ha}^{-1}\right)$ and followed by $100 \mathrm{x}$ $10 \mathrm{~cm}\left(\mathrm{~S}_{3}\right)$ which recorded $73.27 \mathrm{~kg} \mathrm{ha}^{-1}$. The minimum population of 88,888 plants $\mathrm{ha}^{-1}\left(\mathrm{~S}_{2}\right)$ registered the lowest uptake of nitrogen of $68.29 \mathrm{~kg} \mathrm{ha}^{-1}$. In respect of fertilizer dose, application of 150\%RDF-120:60:60 kg NPK $\mathrm{ha}^{-1}\left(\mathrm{~F}_{3}\right)$ recorded the highest $\mathrm{N}$ uptake 91.68 $\mathrm{kg} \mathrm{ha}^{-1}$, while control (no fertilizer) recorded the lowest $\mathrm{N}$ uptake $\left(38.90 \mathrm{~kg} \mathrm{ha}^{-1}\right)$.

Data on $\mathrm{N}$ uptake were significantly influenced by the interaction between spacing and nutrient levels. Similar the both seasons, $\mathrm{S}_{3} \mathrm{~F}_{3}(60 \times 15 \mathrm{~cm}$ with $150 \% \mathrm{RDF})$ recorded the maximum $\mathrm{N}$ uptake $\left(94.39 \mathrm{~kg} \mathrm{ha}^{-1}\right)$ and it was on par with $\mathrm{S}_{1} \mathrm{~F}_{3}(100 \times 10 \mathrm{~cm}$ with $150 \%$ RDF) which registered $93.19 \mathrm{~kg} \mathrm{ha}^{-1}$. The interaction of $75 \times 15 \mathrm{~cm}$ with no fertilizer $\left(\mathrm{S}_{2} \mathrm{C}\right)$ recorded the lowest nitrogen uptake $\left(36.29 \mathrm{~kg} \mathrm{ha}^{-1}\right)$. It was very well evident from the study that compact cotton cv. co 17 with $60 \times 15 \mathrm{~cm}$ i.e., $1,11,111$ plants/ha with 150\% RDF i.e., 120:60:60 kg $\mathrm{ha}^{-1}$ registered the highest nitrogen uptake. This treatment combination was closely followed by $(100 \mathrm{x} 10 \mathrm{~cm}-1,00,000$ plants/ha $\left(\mathrm{S}_{1}\right)$ with $\mathrm{F}_{3}(150 \% \mathrm{RDF})$ which registered a value of $93.19 \mathrm{~kg} \mathrm{ha}^{-1}$. However both of them were on par with each other. Increased availability of nitrogen i.e., $120 \mathrm{~kg}$ $\mathrm{ha}^{-1}$ with optimum plant population could be the probable reason for the enhanced uptake of nitrogen in these two treatment combinations (Nalayini and Manickam, 2018). The results of present study was in consonance with the findings of Jyothi and Hebsur (2017).

\section{Phosphorous uptake}

Phosphorus is the second most limiting nutrient in cotton production after nitrogen. It is a constituent of cell nuclei, essential for cell division and development of meristematic tissue and has a well known impact on photosynthesis as well as synthesis of nucleic 
acids, proteins, lipids and other essential compounds(Guinn, 1984; Taiz and Zeiger, 1991).In the present study, the phosphorous uptake was significantly affected by both plant population and fertilizer levels. In respect of summer season I (2019), analysing uptake of phosphorous due to crop geometry, it was very well evident that optimum plant population treatment $60 \times 15 \mathrm{~cm}\left(\mathrm{~S}_{3}\right)$ recorded the highest phosphorous uptake (11.89 $\left.\mathrm{kg} \mathrm{ha}^{-1}\right)$, followed by $100 \times 10 \mathrm{~cm}\left(\mathrm{~S}_{1}\right)$ which registered $11.36 \mathrm{~kg} \mathrm{ha}^{-1}$ and were found to be on par with each other. The lowest $\mathrm{P}$ uptake $\left(10.21 \mathrm{~kg} \mathrm{ha}^{-1}\right)$ was recorded in spacing of 75 $\mathrm{x} 15 \mathrm{~cm}\left(\mathrm{~S}_{2}\right)$. Comparing the nutrient levels, $150 \%$ RDF $\left(\mathrm{F}_{3}\right)$ registered the highest $\mathrm{P}$ uptake (15.45 kg ha $\mathrm{kg}^{-1}$ as against control (without nutrient application), recorded 5.41 $\mathrm{kg} \mathrm{ha}^{-1}$.

Interaction effect was found to be significant. Here again, similar to nitrogen, combination of $60 \times 15 \mathrm{~cm}$ with $150 \%$ RDF- 120:60:60 kg NPK ha ${ }^{-1}\left(\mathrm{~S}_{3} \mathrm{~F}_{3}\right)$ registered the highest $\mathrm{P}$ uptake $(16.21 \mathrm{k} / \mathrm{ha})$, followed by the combination of $100 \times 10 \mathrm{~cm}-1,00,000$ plants/ha with $150 \%$ RDF $\left(\mathrm{S}_{1} \mathrm{~F}_{3}\right)$ which recorded $15.87 \mathrm{~kg} \mathrm{ha}^{-1}$ and were found to be on par with each other. The lowest $\mathrm{P}$ uptake of $4.76 \mathrm{~kg} \mathrm{ha}^{-1}$ was observed in the treatment combination of $\mathrm{S}_{2} \mathrm{C}$.

With respect to second season (rabi 2019-20), $\mathrm{S}_{3}(60 \times 15 \mathrm{~cm})$ registered the maximum phosphorous uptake (10.69 $\mathrm{kg} \mathrm{ha}^{-1} \mathrm{~kg} \mathrm{ha}^{-1}$ ) followed by $S_{1}\left(10.31 \mathrm{~kg} \mathrm{ha}^{-1}\right)$ and were found to be on par. The minimum phosphorous uptake $\left(9.24 \mathrm{~kg} \mathrm{ha}^{-1}\right)$ was observed in spacing of $75 \times 15 \mathrm{~cm}\left(\mathrm{~S}_{2}\right)$. Among the different nutrient levels, $\mathrm{F}_{3}$ (150\%- 120:60:60 kg NPK $\mathrm{ha}^{-1}$ ) recorded the higher phosphorous uptake (14.05 kg ha ${ }^{-1}$ ), while control (no fertilizer) registered the lowest phosphorous uptake $\left(4.73 \mathrm{~kg} \mathrm{ha}^{-1}\right)$. The interaction effect between crop geometry and nutrient levels was found to be significant. Similar to Nitrogen, the highest $\mathrm{P}$ uptake (14.72 $\left.\mathrm{kg} \quad \mathrm{ha}^{-1}\right)$ was registered in the treatment combination of $\mathrm{S}_{3}$ $(60 \times 15 \mathrm{~cm})$ with $\mathrm{F}_{3}(150 \%$ RDF- 120:60:60 $\mathrm{kg}$ NPK ha $\left.{ }^{-1}\right)$, followed by $\mathrm{S}_{1}(100 \times 10 \mathrm{~cm})$ with $\mathrm{F}_{3}(150 \% \mathrm{RDF})$ which recorded $14.44 \mathrm{~kg}$ $\mathrm{ha}^{-1}$ of phosphorous and these two were found to be on par with each other. The lowest (4.76 $\mathrm{kg} \mathrm{ha}^{-1}$ ) phosphorous uptake was observed in $\mathrm{S}_{2} \mathrm{C}$.

Data on pooled analysis of both season revealed that it was significantly altered by both varied spacing and nutrient levels. Among the different spacing, $S_{3}(60 \times 15 \mathrm{~cm})$ registered the maximum phosphorous uptake $\left(11.28 \mathrm{~kg} \mathrm{ha}^{-1}\right)$ which was followed by $\mathrm{S}_{1}$ $(100 \times 10 \mathrm{~cm})$ which recorded $10.83 \mathrm{~kg} \mathrm{ha}^{-1}$ of $\mathrm{P}$ and found to be on par with each other. With regards to varied fertilizer doses, application of $150 \% \mathrm{RDF}\left(\mathrm{F}_{3^{-}}\right.$120:60:60 kg NPK ha ${ }^{-1}$ ) registered the highest $\mathrm{P}$ uptake $\left(14.75 \mathrm{~kg} \mathrm{ha}{ }^{-1}\right)$; whereas the lowest phosphorous uptake obtained in control plot $\left(5.06 \mathrm{~kg} \mathrm{ha}^{-1}\right)$. The interaction effect was found to be significant. The interaction of $\mathrm{S}_{3} \mathrm{~F}_{3}(60 \times 15 \mathrm{~cm}$ with $150 \% \mathrm{RDF})$ recorded highest $\mathrm{P}$ uptake $\left(15.47 \mathrm{~kg} \mathrm{ha}^{-1}\right)$ and it was followed by $\mathrm{S}_{1} \mathrm{~F}_{3}(100 \times 10 \mathrm{~cm}$ with $150 \%$ RDF) which revealed $15.16 \mathrm{~kg} \mathrm{ha}^{-1}$ and found to be par with each other. On the other hand, the treatment combination $\mathrm{S}_{2} \mathrm{C}(75 \times 15 \mathrm{~cm}$ with no fertilizer) recorded the lowest $\mathrm{P}$ uptake of $5.25 \mathrm{~kg} \mathrm{ha}^{-1}$. It was revealed from the present investigation that the increased phosphorous application increases the phosphorous $\left(\mathrm{F}_{3}\right)$. This available phosphorous could have been exploited by the optimum plant population $1,00,000$ plants/ha $(100 \times 10$ $\mathrm{cm})$ and 1,11,111 plants/ha $(60 \times 15 \mathrm{~cm})$ and hence, these treatment two treatment combination recorded the highest uptake of phosphorous than the other treatment. Similar positive response of cotton to phosphorous was observed by Ahmad et al., (2009) and Gadhiya et al., (2009). 
Table.1 Impact of crop geometries and nutrient levels on nitrogen and phosphorous uptake at harvest stage in compact cotton cv. CO 17 during summer 2019 (season I) and rabi 2019-20 (season II)

\begin{tabular}{|c|c|c|c|c|c|c|}
\hline \multicolumn{7}{|c|}{ Nutrient uptake } \\
\hline Treatments & \multicolumn{3}{|c|}{ Nitrogen uptake $\left(\mathrm{kg} \mathrm{ha}^{-1}\right)$} & \multicolumn{3}{|c|}{ phosphorous uptake $\left.\left(\mathrm{kg} \mathrm{ha}^{-1}\right)\right)$} \\
\hline Crop geometry & Season I & Season II & Pooled & Season I & Season II & Pooled \\
\hline$S_{1}(100 \times 10 \mathrm{~cm})$ & 74.41 & 72.15 & 73.27 & 11.36 & 10.31 & 10.83 \\
\hline$S_{2}(75 \times 15 \mathrm{~cm})$ & 69.77 & 66.83 & 68.29 & 10.21 & 9.24 & 9.72 \\
\hline$S_{3}(60 \times 15 \mathrm{~cm})$ & 76.01 & 73.63 & 74.81 & 11.89 & 10.69 & 11.28 \\
\hline$S_{4}(45 \times 15 \mathrm{~cm})$ & 72.11 & 69.78 & 70.94 & 10.79 & 9.73 & 10.25 \\
\hline SEd & 0.78 & 0.91 & 0.75 & 0.22 & 0.19 & 0.17 \\
\hline CD $(p=0.05)$ & 1.91 & 2.23 & 1.84 & 0.53 & 0.46 & 0.42 \\
\hline \multicolumn{7}{|l|}{ Nutrient levels } \\
\hline C (nil nutrient) & 39.91 & 37.90 & 38.90 & 5.41 & 4.73 & 5.06 \\
\hline $\mathrm{F}_{1}(100 \% \mathrm{RDF})$ & 75.23 & 71.69 & 73.45 & 10.46 & 9.32 & 9.89 \\
\hline $\mathrm{F}_{2}(125 \%$ RDF $)$ & 84.40 & 82.19 & 83.29 & 12.92 & 11.87 & 12.39 \\
\hline $\mathrm{F}_{3}(150 \% \mathrm{RDF})$ & 92.76 & 90.61 & 91.68 & 15.46 & 14.05 & 14.75 \\
\hline SEd & 1.20 & 1.21 & 0.81 & 0.21 & 0.14 & 0.12 \\
\hline $\mathrm{CD}(\mathrm{p}=0.05)$ & 2.48 & 2.50 & 1.63 & 0.43 & 0.30 & 0.24 \\
\hline \multicolumn{7}{|l|}{ Interaction } \\
\hline $\mathrm{S}_{1} \mathrm{C}$ & 41.01 & 39.17 & 40.09 & 5.61 & 4.89 & 5.25 \\
\hline $\mathbf{S}_{1} \mathbf{F}_{1}$ & 76.68 & 73.52 & 75.10 & 10.78 & 9.64 & 10.21 \\
\hline $\mathbf{S}_{1} \mathbf{F}_{2}$ & 85.70 & 83.78 & 84.74 & 13.19 & 12.28 & 12.73 \\
\hline $\mathbf{S}_{\mathbf{1}} \mathbf{F}_{\mathbf{3}}$ & 94.23 & 92.14 & 93.19 & 15.87 & 14.44 & 15.16 \\
\hline $\mathbf{S}_{2} \mathbf{C}$ & 37.62 & 34.95 & 36.29 & 4.76 & 4.32 & 4.54 \\
\hline $\mathbf{S}_{2} \mathbf{F}_{1}$ & 70.55 & 66.22 & 68.39 & 9.53 & 8.42 & 8.98 \\
\hline $\mathbf{S}_{2} \mathbf{F}_{2}$ & 81.53 & 78.81 & 80.17 & 12.01 & 11.02 & 11.52 \\
\hline $\mathbf{S}_{2} \mathbf{F}_{3}$ & 89.38 & 87.32 & 88.35 & 14.53 & 13.21 & 13.87 \\
\hline $\mathbf{S}_{3} \mathbf{C}$ & 42.14 & 40.43 & 41.29 & 6.05 & 5.21 & 5.63 \\
\hline $\mathbf{S}_{3} \mathbf{F}_{1}$ & 79.42 & 75.97 & 77.70 & 11.42 & 10.21 & 10.82 \\
\hline $\mathbf{S}_{3} \mathbf{F}_{2}$ & 86.92 & 84.89 & 85.91 & 13.86 & 12.62 & 13.24 \\
\hline $\mathbf{S}_{\mathbf{3}} \mathbf{F}_{\mathbf{3}}$ & 95.55 & 93.22 & 94.39 & 16.21 & 14.72 & 15.47 \\
\hline $\mathrm{S}_{\mathbf{4}} \mathrm{C}$ & 38.87 & 37.05 & 37.96 & 5.20 & 4.51 & 4.86 \\
\hline $\mathbf{S}_{4} \mathbf{F}_{1}$ & 74.25 & 71.04 & 72.65 & 10.11 & 9.02 & 9.57 \\
\hline $\mathbf{S}_{4} \mathbf{F}_{2}$ & 83.44 & 81.26 & 82.35 & 12.60 & 11.57 & 12.09 \\
\hline $\mathbf{S}_{4} \mathbf{F}_{3}$ & 91.86 & 89.77 & 90.82 & 15.24 & 13.81 & 14.52 \\
\hline SEd & 2.22 & 2.29 & 2.30 & 0.42 & 0.31 & 0.35 \\
\hline CD $(p=0.05)$ & 4.62 & 4.76 & 4.78 & 0.65 & 0.87 & 0.73 \\
\hline
\end{tabular}


Table.2 Impact of crop geometries and nutrient levels on potassium uptake at harvest stage and seed cotton yield of compact cotton cv. CO 17 during summer 2019 (season I) and rabi 2019-20

(season II)

\begin{tabular}{|c|c|c|c|c|c|c|}
\hline \multirow{2}{*}{$\begin{array}{l}\text { Treatments } \\
\text { Crop geometry }\end{array}$} & \multicolumn{3}{|c|}{ Potassium uptake $\left(\mathrm{kg} \mathrm{ha}^{-1}\right)$} & \multicolumn{3}{|c|}{ Seed cotton yield $\left(\mathrm{kg} \mathrm{ha}^{-1}\right)$} \\
\hline & Season I & Season II & Pooled & Season I & Season II & Pooled \\
\hline$S_{1}(100 \times 10 \mathrm{~cm})$ & 63.75 & 61.81 & 62.78 & 1801 & 1676 & 1739 \\
\hline$S_{2}(75 \times 15 \mathrm{~cm})$ & 57.51 & 54.79 & 56.15 & 1582 & 1458 & 1520 \\
\hline$S_{3}(60 \times 15 \mathrm{~cm})$ & 65.68 & 63.40 & 64.53 & 1884 & 1747 & 1816 \\
\hline$S_{4}(45 \times 15 \mathrm{~cm})$ & 60.34 & 58.89 & 59.61 & 1344 & 1239 & 1292 \\
\hline SEd & 1.02 & 0.73 & 0.73 & 34 & 31 & 28 \\
\hline $\mathrm{CD}(\mathrm{p}=0.05)$ & 2.50 & 1.80 & 1.80 & 84 & 75 & 70 \\
\hline \multicolumn{7}{|l|}{ Nutrient levels } \\
\hline C (nil nutrient) & 36.61 & 35.38 & 35.99 & 858 & 792 & 825 \\
\hline$F_{1}(100 \%$ RDF $)$ & 57.02 & 53.76 & 55.38 & 1914 & 1770 & 1842 \\
\hline $\mathrm{F}_{2}(125 \% \mathrm{RDF})$ & 70.90 & 68.91 & 69.90 & 2216 & 2053 & 2135 \\
\hline $\mathrm{F}_{\mathbf{3}}(\mathbf{1 5 0 \%} \mathrm{RDF})$ & 82.77 & 80.84 & 81.80 & 1623 & 1506 & 1565 \\
\hline SEd & 0.92 & 1.13 & 0.71 & 25 & 21 & 19 \\
\hline $\mathrm{CD}(\mathrm{p}=0.05)$ & 1.91 & 2.34 & 1.42 & 52 & 43 & 29 \\
\hline \multicolumn{7}{|l|}{ Interaction } \\
\hline$S_{1} \mathbf{C}$ & 37.58 & 36.14 & 36.86 & 830 & 761 & 796 \\
\hline $\mathbf{S}_{1} \mathbf{F}_{1}$ & 58.72 & 55.41 & 57.07 & 2134 & 1989 & 2062 \\
\hline$S_{1} F_{2}$ & 73.71 & 72.22 & 72.97 & 2485 & 2304 & 2395 \\
\hline $\mathbf{S}_{1} \mathbf{F}_{3}$ & 84.99 & 83.48 & 84.24 & 1754 & 1649 & 1702 \\
\hline $\mathbf{S}_{\mathbf{2}} \mathbf{C}$ & 33.68 & 32.22 & 32.95 & 733 & 677 & 705 \\
\hline $\mathbf{S}_{2} \mathbf{F}_{1}$ & 51.90 & 48.76 & 50.33 & 1978 & 1826 & 1902 \\
\hline $\mathbf{S}_{2} \mathbf{F}_{2}$ & 66.50 & 62.56 & 64.53 & 2343 & 2165 & 2254 \\
\hline $\mathbf{S}_{2} \mathbf{F}_{3}$ & 77.97 & 75.63 & 76.80 & 1273 & 1164 & 1219 \\
\hline $\mathbf{S}_{3} \mathbf{C}$ & 39.44 & 38.32 & 38.88 & 901 & 836 & 869 \\
\hline $\mathbf{S}_{\mathbf{3}} \mathbf{F}_{\mathbf{1}}$ & 62.14 & 58.72 & 60.43 & 2202 & 2033 & 2118 \\
\hline $\mathbf{S}_{3} \mathbf{F}_{2}$ & 74.67 & 72.15 & 73.41 & 2563 & 2387 & 2475 \\
\hline $\mathbf{S}_{\mathbf{3}} \mathbf{F}_{\mathbf{3}}$ & 86.48 & 84.39 & 85.44 & 1869 & 1731 & 1800 \\
\hline $\mathbf{S}_{4} \mathbf{C}$ & 35.72 & 34.85 & 35.29 & 966 & 892 & 929 \\
\hline$S_{4} F_{1}$ & 55.31 & 52.13 & 53.72 & 1343 & 1230 & 1287 \\
\hline $\mathbf{S}_{4} \mathbf{F}_{2}$ & 68.72 & 68.72 & 68.72 & 1471 & 1355 & 1413 \\
\hline $\mathbf{S}_{4} \mathbf{F}_{3}$ & 81.62 & 79.84 & 80.73 & 1596 & 1478 & 1537 \\
\hline SEd & 1.90 & 2.10 & 2.00 & 55 & 48 & 42 \\
\hline $\mathrm{CD}(\mathrm{p}=\mathbf{0 . 0 5})$ & 3.95 & 4.36 & 4.16 & 123 & 106 & 85 \\
\hline
\end{tabular}




\section{Potassium uptake}

Potassium is an essential macroelement for all living organisms required in large amounts for normal plant growth and development (Marschner, 1995). In higher plant cytoplasm, $\mathrm{K}$ is the dominant cation and is commonly found to be in concentrations ranging from 80 to $150 \mathrm{mM}$ (Blevins, 1985). Its primary role is as an enzyme activator. It has been implicated in over 60 enzymatic reactions (Evans and Sorger, 1966) which are involved in many processes in the plant such as photosynthesis, respiration, carbohydrate metabolism, translocation and protein synthesis. Potassium balances charges of anions and influences their uptake and transport. Another major role of $\mathrm{K}$ is in photosynthesis (Steven, 1985) by directly increasing leaf growth and leaf area index, and therefore, $\mathrm{CO} 2$ assimilation(Wolf et al., 1976). Potassium increases the outward translocation of photosynthate from the leaf(Ashley and Goodson, 1972).In the present investigation, the potassium uptake was significantly influenced by both crop geometry and levels of nutrients (Table 2). In respect of summer season 2019 (season I), analysing the data pertaining to the plant spacing revealed that $60 \times 15 \mathrm{~cm}\left(\mathrm{~S}_{3}\right)$ recorded the highest $\mathrm{K}$ uptake $\left(65.68 \mathrm{~kg} \mathrm{ha}^{-1}\right)$ which was followed by $100 \times 10 \mathrm{~cm}\left(\mathrm{~S}_{1}\right)$ recorded $63.75 \mathrm{~kg} \mathrm{ha}^{-1}$; Whereas crop geometry of $75 \times 15 \mathrm{~cm}\left(\mathrm{~S}_{2}\right)$ registered the $\mathrm{K}$ lowest uptake $\left(57.51 \mathrm{~kg} \mathrm{ha}^{-1}\right)$. Among the sub plot treatments (nutrient levels), application of 150\% RDF- 120:60:60 kg NPK ha-1 $\left(\mathrm{F}_{3}\right)$ recorded the highest $\mathrm{K}$ uptake $\left(82.77 \mathrm{~kg} \mathrm{ha}^{-1}\right)$ as against control plot (without fertilizer) which recorded the lowest K uptake $(36.61 \mathrm{~kg}$ $\left.\mathrm{ha}^{-1}\right)$. The interaction effect was found to be significant. With regards to interaction effect, the treatment combination of $60 \times 15 \mathrm{~cm}$ with $150 \% \operatorname{RDF}\left(\mathrm{S}_{3} \mathrm{~F}_{3}\right)$ registered the highest $\mathrm{K}$ uptake $\left(86.48 \mathrm{~kg} \mathrm{ha}^{-1}\right)$ and was followed by $\mathrm{S}_{1} \mathrm{~F}_{3}\left(84.99 \mathrm{~kg} \mathrm{ha}^{-1}\right)$ and were found to be on par with each other. The lower $\mathrm{K}$ uptake was reported from the plants which received no fertilizers (control) in $75 \times 15 \mathrm{~cm}\left(\mathrm{~S}_{2}\right)$ which registered $33.68 \mathrm{~kg} \mathrm{ha}^{-1}$.

In the case of rabi season of 2019-20 (season II), crop geometry was significantly influenced the $\mathrm{K}$ uptake. The highest $\mathrm{K}$ uptake $\left(63.40 \mathrm{~kg} \mathrm{ha}^{-1}\right)$ was registered in $\mathrm{S}_{3}(60$ x $15 \mathrm{~cm})$ and was followed by $S_{1}(61.81 \mathrm{~kg}$ $\mathrm{ha}^{-1}$ ) and were found to be on par with each other. The lowest uptake $\left(54.79 \mathrm{~kg} \mathrm{ha}^{-1}\right)$ was registered in $45 \times 15 \mathrm{~cm}\left(\mathrm{~S}_{4}\right)$. With regard to fertilizer levels, 150\% RDF- 120:60:60 kg NPK ha ${ }^{-1}\left(F_{3}\right)$ recorded the maximum $\mathrm{K}$ uptake (80.84 $\mathrm{kg} \mathrm{ha}^{-1}$ ) as against control (nil nutrient application) which recoreded 35.38 $\mathrm{k} / \mathrm{ha}$. Similar to first season, here again, significant interaction was observed between crop geometry and fertilizer levels. The treatment combination of $60 \times 15 \mathrm{~cm}$ with $150 \%$ RDF $\left(\mathrm{S}_{3} \mathrm{~F}_{3}\right)$ registered the highest $\mathrm{K}$ uptake $\left(84.39 \mathrm{~kg} \mathrm{ha}^{-1}\right)$ followed by $\mathrm{S}_{1} \mathrm{~F}_{3}$ $\left(83.48 \mathrm{~kg} \mathrm{ha}^{-1}\right)$ and these two treatments were on par with each other. The lowest uptake of $\mathrm{K}\left(32.22 \mathrm{~kg} \mathrm{ha}^{-1}\right)$ was registered by $75 \times 15$ $\mathrm{cm}$ with no fertilizer $\left(\mathrm{S}_{2} \mathrm{C}\right)$.

The pooled analysis of both season revealed that it followed trend similar to that of both seasons. Among the plant populations, $1,11,111$ plants/ha $\left(\mathrm{S}_{3}\right)$ registered the maximum $\mathrm{K}$ uptake $\left(64.53 \mathrm{~kg} \mathrm{ha}^{-1}\right)$ followed by population of $1,00,000$ plants/ha $\left(S_{1}\right)$ which recorded $62.78 \mathrm{~kg} \mathrm{ha}^{-1}$. These treatments were found to be on par with each other. The lowest $\mathrm{K}$ uptake registered by $75 \mathrm{x}$ $15 \mathrm{~cm}\left(\mathrm{~S}_{2}\right)$ which recorded $56.15 \mathrm{~kg} \mathrm{ha}^{-1}$. Fertilizer level significantly enhanced the $\mathrm{K}$ uptake and $F_{3}(150 \%$ RDF- 120:60:60 kg NPK $\mathrm{ha}^{-1}$ ) recorded the maximum $\mathrm{K}$ uptake $\left(81.80 \mathrm{~kg} \mathrm{ha}^{-1}\right)$. The untreated plot (control) registered the lowest $\mathrm{K}$ uptake (35.99 $\mathrm{kg} \mathrm{ha}^{-1}$ ). The interaction effect was found to be significant. Similar to the other two seasons, the pooled analysis also registered the highest uptake of $\mathrm{K}\left(85.44 \mathrm{~kg} \mathrm{ha}^{-1}\right)$ in $\mathrm{S}_{3} \mathrm{~F}_{3}$, followed 
by $100 \times 10 \mathrm{~cm}$ along with $150 \% \operatorname{RDF}\left(\mathrm{S}_{1} \mathrm{~F}_{3}\right)$ which reorded84.24 $\mathrm{kg} \mathrm{ha}^{-1}$ and were on par with each other. The lowest K uptake (32.95 $\mathrm{kg} \mathrm{ha} \mathrm{h}^{-1}$ ) was registered in the treatment combination of Spacing of $75 \times 15 \mathrm{~cm}$ with no fertilizer $\left(\mathrm{S}_{2} \mathrm{C}\right)$. It was well documented from the present study that increased level of fertilizer application increases the potassium uptake. This may be due to the fact that application of $\mathrm{K}$ increases $\mathrm{K}^{+}$availability in the soil which was efficiently absorbed by the optimum plant population in both $S_{1}$ and $S_{3}$ and resulted in highest uptake of $\mathrm{K}$ in these two treatment combination than the others. The above results are in close conformity with the findings of Mullins and Burmester (1990), Modhvadia et al., (2012) and (Hiwale et al., 2018).

\section{Seed cotton yield}

Seed cotton yield is the result of translocation efficiency of biomass into the economic yield. It is the combined effect of various yield components under particular environmental conditions. It is evident from the data illustrated in Table 2 that both varying plant spacing and different nutrients level had significant effect on seed cotton yield. The seed cotton yield of summer season of 2019 (season I) indicated that plant spacing significantly influenced the seed cotton yield. Spacing of $60 \times 15 \mathrm{~cm}\left(\mathrm{~S}_{3}\right)$ recorded the highest seed cotton yield (1884 $\left.\mathrm{kg} \mathrm{ha}^{-1}\right)$, followed by $100 \times 10 \mathrm{~cm}\left(\mathrm{~S}_{1}\right)$ recorded 1804 $\mathrm{kg} \mathrm{ha}{ }^{-1}$. However, $S_{1}$ and $S_{3}$ were on par with each other. The lowest yield of seed cotton $\left(1344 \mathrm{~kg} \mathrm{ha}^{-1}\right)$ was registered in crop geometry of $45 \times 15 \mathrm{~cm}\left(\mathrm{~S}_{4}\right)$. Nutrient levels strongly influenced the seed cotton yield. Among the treatments, $125 \%$ RDF-100:50:50 kg NPK $\mathrm{ha}^{-1}\left(\mathrm{~F}_{2}\right)$ registered the maximum seed cotton yield of $2216 \mathrm{~kg} \mathrm{ha}^{-1}$; whereas the lower seed cotton yield $\left(858 \mathrm{~kg} \mathrm{ha}^{-1}\right)$ was obtained from the untreated control. The interaction effect between treatments of main plot and sub plot was found to be significant. It is evident from the data that $60 \times 15 \mathrm{~cm}$ with $125 \% \mathrm{RDF}$ 100:50:50 kg NPK ha ${ }^{-1}\left(\mathrm{~S}_{3} \mathrm{~F}_{2}\right)$ has been judged as the best treatment combination as it registered the $\left(2563 \mathrm{~kg} \mathrm{ha}^{-1}\right)$ highest seed cotton yield and it was followed by $100 \times 10$ cm with $125 \%$ RDF $\left(\mathrm{S}_{1} \mathrm{~F}_{2}\right)$ which recorded the second best seed cotton yield of $2585 \mathrm{~kg}$ $\mathrm{ha}^{-1}$. However, $60 \times 15 \mathrm{~cm}$ with $125 \% \mathrm{RDF}$ $\left(\mathrm{S}_{3} \mathrm{~F}_{2}\right)$ and $100 \times 10 \mathrm{~cm}$ with $125 \% \mathrm{RDF}$ $\left(\mathrm{S}_{1} \mathrm{~F}_{2}\right)$ were on par with each other. The plants from unfertilized control plot recorded the lowest seed cotton yield of $733 \mathrm{~kg} \mathrm{ha}^{-1}$.

The seed cotton yield of second season (rabi season of 2019-20) was found to be lower than the first season crop. Favourable climatic condition prevailed during the summer season of 2019 might be the probable reason for higher seed cotton yield in first season. Lower temperature and poor sunlight are the probable causes which might have been the limiting factor for lower seed cotton yield in the second season (rabi season of 2019-20). Analysing the seed cotton yield performance due to the crop geometry, it was revealed that spacing of $60 \times 15 \mathrm{~cm} \quad\left(\mathrm{~S}_{3}\right)$ recorded significantly the highest seed cotton yield $\left(1747 \mathrm{~kg} \mathrm{ha}^{-1}\right)$ and it was followed by $100 \mathrm{x}$ $10 \mathrm{~cm}\left(\mathrm{~S}_{1}\right)$ of $1676 \mathrm{~kg} \mathrm{ha}^{-1}$ and both $\mathrm{S}_{3}$ and $\mathrm{S}_{1}$ were found to be on par with each other; whereas the lowest seed cotton yield $(1239 \mathrm{~kg}$ $\mathrm{ha}^{-1}$ ) was obtained in the spacing of $45 \times 15$ $\mathrm{cm}\left(\mathrm{S}_{4}\right)$. With regard to nutrient levels, application of 125\% RDF- 100:50:50 kg NPK ha $^{-1}\left(\mathrm{~F}_{2}\right)$ recorded significantly the highest seed cotton yield $\left(2053 \mathrm{~kg} \mathrm{ha}^{-1}\right)$ and the lowest seed cotton yield $\left(792 \mathrm{~kg} \mathrm{ha}^{-1}\right)$ in control. The interaction effect was found to be significant. Similar to the previous season, here again, the treatment combination of $60 \times 15 \mathrm{~cm}$ with $125 \%$ RDF $\left(\mathrm{S}_{3} \mathrm{~F}_{2}\right)$ registered the maximum seed cotton yield ( $\left.2387 \mathrm{~kg} \mathrm{ha}^{-1}\right)$, followed by $100 \times 10 \mathrm{~cm}$ with $125 \%$ RDF $\left(\mathrm{S}_{1} \mathrm{~F}_{2}\right)$ of 2304 $\mathrm{kg}$ ha ${ }^{-1}$ and both $\mathrm{S}_{3} \mathrm{~F}_{2}$ and $\mathrm{S}_{1} \mathrm{~F}_{2}$ were on par with each other. The lowest seed cotton yield 
$\left(677 \mathrm{~kg} \mathrm{ha}^{-1}\right)$ was obtained in $75 \times 15 \mathrm{~cm}$ $\left(\mathrm{S}_{2} \mathrm{C}\right)$.

The pooled data of both seasons revealed that the crop geometry as well as nutrient levels had significant effect on seed cotton yield. Among the spacing, $60 \times 15 \mathrm{~cm}\left(\mathrm{~S}_{3}\right)$ recorded the highest $\left(1815 \mathrm{~kg} \mathrm{ha}^{-1}\right)$, followed by $100 \mathrm{x}$ $10 \mathrm{~cm}\left(\mathrm{~S}_{1}\right)$ registered the seed cotton yield of $1738 \mathrm{~kg} \mathrm{ha}^{-1}$ and the treatments $\mathrm{S}_{3}$ and $S_{1}$ were found to be on par with each other. The lowest seed cotton yield of $1291 \mathrm{~kg} \mathrm{ha}^{-1}$ was obtained in plots from closer spacing 45 x 15 $\mathrm{cm}$ with higher populations. Nutrient levels significantly altered the seed cotton yield. Fertilizer application@125\%-100:50:50 kg NPK ha ${ }^{-1}\left(\mathrm{~F}_{2}\right)$ recorded the higher seed cotton yield $\left(2134 \mathrm{~kg} \mathrm{ha}^{-1}\right)$ as against the control (without fertilizer) which registered lowest seed cotton of $824 \mathrm{~kg} \mathrm{ha}^{-1}$.

It could be inferred from the pooled analysis that the highest seed cotton yield $\left(2475 \mathrm{~kg} \mathrm{ha}^{-}\right.$ $\left.{ }^{1}\right)$ was recorded in $S_{3} F_{2}(60 \times 15 \mathrm{~cm}$ with 125\% RDF- 100:50:50 kg NPK ha $\left.{ }^{-1}\right)$ and it was followed $\mathrm{S}_{1} \mathrm{~F}_{2}(100 \times 10 \mathrm{~cm}$ with $125 \%$ RDF- 100:50:50 kg NPK ha ${ }^{-1}$ ) which recorded $2395 \mathrm{~kg} \mathrm{ha}^{-1}$. This could be probably due to the fact that optimum plant population $\left(S_{3}\right.$ and $\left.S_{1}\right)$ could have utilized the applied $N$, $\mathrm{P}$ and $\mathrm{K}$. In this study, the uptake of $\mathrm{N}, \mathrm{P}$ and $\mathrm{K}$ was found to be high in $150 \% \mathrm{RDF}$ 120:60:60 kg NPK ha ${ }^{-1}\left(F_{3}\right)$. But all the absorbed nutrients are not effectively used for boll formation and cotton productivity. However, $\mathrm{S}_{4} \quad\left(\begin{array}{llll}45 & \mathrm{x} & 15 & \mathrm{~cm}\end{array}\right)$ spacing accommodating higher plant population could resulted in reduced yield due to intra plant competition for nutrition, space, air and light. Hence, higher plant population and nutrient levels unable to increase the seed cotton yield as they limit the yield components. That is why $S_{1}$ and $S_{3}$ with $125 \%$ RDF $\left(F_{2}-100: 50: 50\right.$ $\mathrm{kg}$ NPK ha ${ }^{-1}$ ) could optimize the effective utilization of bio-resources and hence higher cotton productivity. This was in accordance with the earlier findings of Paslawar et al., (2015) and Parlawar et al., (2017).

On the basis of two seasons data, it could be concluded that application of 120:60:60 kg NPK ha ${ }^{-1}$ with $11,11,111$ plants/ha $(60 \times 15$ $\mathrm{cm})$ and 120:60:60 kg NPK ha ${ }^{-1}$ with 1,00,000 plants/ha $(100 \times 10 \mathrm{~cm})$ recorded higher $\mathrm{N}, \mathrm{P}$ and $\mathrm{K}$ uptake than the other treatments. However, the higher seed cotton yield of 2475 $\mathrm{kg} \mathrm{ha}^{-1}$ and $2395 \mathrm{~kg} \mathrm{ha}^{-1} \mathrm{~kg} \mathrm{ha}^{-1}$ were obtained in the treatment combinations of $60 \times 15 \mathrm{~cm}$ with 125\% RDF- 100:50:50 kg NPK ha ${ }^{-1}$ $\left(\mathrm{S}_{3} \mathrm{~F}_{2}\right)$ and $100 \times 10 \mathrm{~cm}$ with $125 \% \mathrm{RDF}-$ 100:50:50 kg NPK ha $\mathrm{ha}^{-1}\left(\mathrm{~S}_{3} \mathrm{~F}_{2}\right)$ respectively. However, these two treatment combinations were not differed statistically.

\section{References}

Ahmad, M., A. Hannan, M. Yasin, A.M. Ranjha, and Niaz, A. 2009. "Phosphorus application to cotton enhances growth, yield, and quality characteristics on a sandy loam soil." Pak. J. Agri. Sci 46:3.

Ali, M.A., M. Ali, K. Yar, and Yamin, M. 2007. "Effect of nitrogen and plant population levels on seed cotton yield of newly introduced cotton variety CIM-497." Journal of Agricultural Research (Pakistan).

Ashley, D.A., and Goodson, R.D. 1972. "Effect of Time and Plant K Status on 14C-labeled Photosynthate Movement in Cotton 1." Crop science 12 (5):686690.

Balakrishnan, K., J. Rajangam, T. Ragavan, A. Subbiah, K.K. Surendar, Devaraju, M. Prakash, and Paulpandi, V.K. 2020. Research Methodology for Agricultural Science. vols. Vol. 1: International Books \& Periodical Supply Service.

Blevins, D.G. 1985. "Role of potassium in protein metabolism in plants." 
Potassium in agriculture:413-424.

Bondada, B.R., D.M. Oosterhuis, R.J. Norman, and Baker, W.H. 1996. "Canopy photosynthesis, growth, yield, and boll $15 \mathrm{~N}$ accumulation under nitrogen stress in cotton." Crop science 36 (1):127-133.

Boquet, D.J., E.B. Moser, and Breitenbeck, G.A. 1993. "Nitrogen effects on boll production of field-grown cotton." Agronomy journal 85 (1):34-39.

Evans, H.J., and Sorger, G.J. 1966. "Role of mineral elements with emphasis on the univalent cations." Annual review of plant physiology 17 (1):47-76.

Gadhiya, S.S., B.B. Patel, N.J. Jadav, R.P. Pavaya, M.V. Patel, and Patel, V.R. 2009. "Effect of different levels of nitrogen, phosphorus and potassium on growth, yield and quality of $\mathrm{Bt}$ cotton. Asian Journal of Soil Science 4 (1):37-42.

Guinn, G. 1984. Potential for improving production efficiency with growth regulants. 1984.

Hiwale, S.D., V.K. Khargakharate, S.S. Patil, and A.D. Nichal. 2018. "Effect of Hirsutum Cotton to High Plant Density and Fertilizer Doses on Yield and Nutrient Uptake under Rainfed Condition. Int.J.Curr.Microbiol.App. Sci (2018) (6):2653-2658.

Hou, Z., P. Li, B. Li, J. Gong, and Wang, Y. 2007. "Effects of fertigation scheme on $\mathrm{N}$ uptake and $\mathrm{N}$ use efficiency in cotton." Plant and Soil 290 (1-2):115126.

Jyothi, T.V., and Hebsur, N.S. 2017. "Nutrient uptake and soil fertility status after harvest of Bt cotton as influenced by graded levels of NPK fertilizers in Alfisol." Journal of Applied and Natural Science 9 (4):2315-2326.

Kharagkharate, V.K., M. Ghanbahadur, S. Hiwale, P. Chirde, and Shaikh, S.A.
2017. "Effect of high density planting, nutrient management and moisture conservation on economics and nutrient uptake of hirsutum cotton under rainfed condition." International Journal of Pure and Applied Bioscience 5 (6):1210-1217.

Marschner, H. 1995. Mineral nutrition of higher plants. Institute of Plant Nutrition, University of Hohenheim. Academic Press, Harcour Brace, London.

Modhvadia, J.M., R.M. Solanki, J.N. Nariya, K.N. Vadaria and Rathod, A.D. 2012. "Effect of different levels of nitrogen, phosphorus and potassium on growth, yield and quality of Bt cotton hybrid under irrigated conditions. Journal of Cotton Research and Development 26 (1):47-51.

Mullins, G.L., and Burmester, C.H. 1990. "Dry matter, nitrogen, phosphorus, and potassium accumulation by four cotton varieties." Agronomy journal 82 (4):729-736.

Nalayini, P., and Manickam, S. 2018. "Agronomic manipulation of high strength cotton genotype, $\mathrm{CCH} 4474$ for yield maximization under irrigated agro ecosystem of Coimbatore." 32:256-259.

Parlawar, N.D., D.J. Jiotode, V.S. Khawle, K.J. Kubde, and Puri, P.D. 2017. "Effect of Planting Geometry and Varieties on Morpho-Physiological Parameters and Yield of Cotton." IJRBAT 5 (2):429-436.

Paslawar, A.N., A.S. Deotalu, and Nemade, P.W. 2015. "High-density planting of cotton variety $\mathrm{AKH}-081$ under rainfed condition of Vidharbha." Plant archives 15 (2):1075-1077.

Patel, P., J.C. Patel, K.G. Vyas, and Salvi, D. 2016. "Effect of hybrids and varying planting time on growth and productivity in cotton (Gossypium 
hirsutum L.). The Bioscan 11 (1):289291.

Shah, A.N., J. Iqbal, M. Tanveer, G. Yang, W. Hassan, S. Fahad, M. Yousaf, and Wu, Y. 2017. "Nitrogen fertilization and conservation tillage: a review on growth, yield, and greenhouse gas emissions in cotton. Environ Sci Pollut Res Int 24 (3):2261-2272. doi: 10.1007/s11356-016-7894-4.

Steven, H.C. 1985. Role of potassium in photosynthesis and respiration. Potassium in agriculture: Pp. 369396.
Taiz, L., and Zeiger, E. 1991. Plant physiology. Redwood City. Plant Physiology: Redwood City.

Venugopalan, M., K. Kranthi, D. Blaise, S. Lakde and Sankaranarayana, K. 2014. "High density planting system in cotton-The Brazil Experience and Indian Initiatives."

Wolf, D.D., E.L. Kimbrough, and Blaser, R.E. 1976. "Photosynthetic Efficiency of Alfalfa with Increasing Potassium Nutrition 1." Crop science 16 (2):292294.

\section{How to cite this article:}

Arun, A., T. Ragavan, A. Gurusamy, P. Saravana Pandian and Gunasekaran, M. 2021. Agronomic Manipulation on Seed Cotton Yield and Nitrogen, Phosphorus and Potassium uptake in Compact Cotton cv. co 17. Int.J.Curr.Microbiol.App.Sci. 10(01): 231-241. doi: https://doi.org/10.20546/ijcmas.2021.1001.028 